\title{
Assessment of proteolysis and lipolysis in Serra cheese: effects of axial cheese location, ripening time and lactation season
}

\author{
AC Macedo, ML Costa, FX Malcata* \\ Escola Superior de Biotecnologia, Universidade Católica Portuguesa, \\ Rua Dr António Bernardino de Almeida, 4200 Porto, Portugal
}

(Received 28 September 1994; accepted 15 December 1995)

\begin{abstract}
Summary - The degrees of proteolysis and lipolysis in Serra cheese were measured in cheese samples obtained from experiments laid out as a three-way factorial design replicated twice. The independent variables studied were the location within the cheese (from the center to the surface), the position in the lactation season (from October to June) and the ripening time (from 0 to 35 days). All three variables had statistically significant effects on the concentration of water soluble peptides (WSP), but only the ripening time and the period within the lactation season affected the fat acidity (FA). The extents (after the given ripening period) and the rates (averaged over the ripening period) of generation of WSP and FA were highest for spring and lowest for autumn. The lowest values for both the proteolysis extent and the proteolysis rate were obtained for the rind. The rates of proteolysis and lipolysis tended to decrease with ripening time; most of the lipolysis occurred during the first week, but proteolysis was still in progress by 35 days of ripening.
\end{abstract}

Serra cheese / proteolysis / lipolysis / ripening / lactation season / axial cheese location

Résumé - Évaluation de la protéolyse et de la lipolyse dans le fromage Serra : effets de la position axiale dans le fromage, du temps d'affinage, et de la saison de lactation. Les taux de protéolyse et lipolyse dans le fromage Serra ont été mesurés dans des échantillons obtenus à partir d'un modèle expérimental à trois facteurs et deux répétitions. Les facteurs indépendants étudiés ont été la position dans le fromage (du centre à la surface), le stade dans la saison de lactation (d'octobre à juin) et le temps d'affinage (de 0 à 35 jours). Les trois facteurs ont eu statistiquement des effets significatifs sur la concentration en peptides solubles dans l'eau (PSE), mais seuls le temps d'affinage et le stade dans la saison de lactation ont affecté l'acidité de la matière grasse (AMG). Les niveaux (après la période d'affinage choisie) et les taux (moyennés au cours de la période d'affinage choisie) de production de PSE et AMG étaient au plus haut pendant le printemps et au plus bas pendant l'automne. Les valeurs minimales obtenues pour le niveau et le taux de protéolyse ont été mesurés sur la croûte du fromage. Les taux de protéolyse et de lipolyse tendaient à décroître avec le temps d'affinage. La quasi-totalité de la lipolyse est apparue au cours de la première semaine, mais la protéolyse était encore en augmentation après 35 jours d'affinage.

Correspondence and reprints. 
fromage Serra / protéolyse / lipolyse / affinage / saison de lactation / localisation axiale dans le fromage

\section{INTRODUCTION}

Serra cheese is the most widely known farm cheese manufactured from raw ewe's milk in Portugal, and was the first to be legally protected by an Appellation d'origine contrôlée. It is made twice daily, usually from October to June, using raw ewe's milk mostly from the Bordaleira breed. In the classical manufacture of Serra, coagulation occurs at ca $30^{\circ} \mathrm{C}$ after addition of a vegetable rennet obtained from an aqueous infusion of dried flowers of wild thistle (Cynara cardunculus L) in the complete absence of any deliberately added starter culture. The gel is then manually cut into small pieces, molded to the form of a flat cylinder and rubbed with crude kitchen salt on both surfaces. Ripening conditions in the maturation room are chiefly determined by the outer temperature and humidity. After a ripening period of ca 45 days, a typical Serra cheese has a flat-cylinder shape without sharp edges, with a diameter of ca $17 \mathrm{~cm}$, a height of $\mathrm{ca} 5 \mathrm{~cm}$ and a weight of ca $1.5 \mathrm{~kg}$. The rind (which is periodically washed with warm water during ripening) is thin, uniform, smooth and well formed, and possesses a soft straw-yellow color. The cheese has a few small eyes, and its color ranges from ivory to white. It has a buttery texture, which leads to spontaneous and rapid deformation upon slicing, and possesses a strong aroma and a clean, smooth, slightly acid flavor (Macedo et al, 1993).

As emphasized elsewhere (Macedo et al, 1993), statistically reliable data pertaining to the microbiological and biochemical changes that occur during ripening of Serra cheese are scarce and mostly outdated (Antunes and Santos, 1943; Cruz and Borrego, 1948; Santos, 1957; Vieira de Sá et al, 1970; Vieira de Sá and Barbosa,
1982; Barbosa, 1986). Recently, Macedo et al $(1994 a, b)$ have extensively characterized both the qualitative and the quantitative microbiological changes that occur during ripening of this cheese. The aim of this research effort was thus to complement these studies by providing estimates of the degree of proteolysis and lipolysis over a 35-day ripening period, throughout the lactation season and at various axial locations within the cheese; the strategy was to lay out a priori a replicated threeway factorial design, and to assess a posteriori the statistical significance of all three factors (and their interactions) on those biochemical processes.

\section{MATERIALS AND METHODS}

\section{Manufacture and sampling}

The cheeses were manufactured in a small dairy farm in three sequential periods within the lactation season (viz November, February and May) from duplicated batches of four $0.5-\mathrm{kg}$ cheeses each with 1 week interval between replicates. Cheesemaking followed traditional practices: after the temperature of previously filtered raw ewe's milk had reached $28^{\circ} \mathrm{C}$, crude kitchen salt was added to a ratio of $12 \mathrm{~g} / \mathrm{L}$ and the milk was stirred until complete solubilization occurred. Thistle was mixed with tap water until a brown suspension was obtained, filtered through a fine, clean cloth and the clear filtrate was added to the milk ( $0.4 \mathrm{~g}$ of dry crude thistle per liter of milk) and gently stirred; the milk was then allowed to rest at $28^{\circ} \mathrm{C}$ until complete coagulation had occurred (a status that was empirically assessed by the cheesemaker upon gentle shaking of the coagulation vat). The curd was manually cut by stirring the coagulum with the bare hand; $10 \mathrm{~min}$ later, the curd pieces were poured into a fine cloth bag and lightly pressed so as to help in the expulsion of whey. Drainage of whey was completed via pressing of the fresh cheese while in the plastic perforated mold by a $10-\mathrm{kg}$ metal block for $12 \mathrm{~h}$ (after $6 \mathrm{~h}$, the weight was momen- 
tarily relieved and the cheese was turned upside down). Final salting was done by rubbing the whole outer surface of the cheese with kitchen salt at a ratio of $15 \mathrm{~g} / \mathrm{cm}^{2}$. After $12 \mathrm{~h}$ of salting, the cheeses were put in ripening chambers maintained at a temperature of $9^{\circ} \mathrm{C}$ and a relative humidity of $95 \%$. The cheeses were turned upside down daily for the whole duration of ripening. Two cheeses in the curd form and two cheeses ripened for 7,21 and 35 days were sent to our laboratory under refrigerated conditions (ca $4^{\circ} \mathrm{C}$ ). Each cylindrically shaped cheese was then divided into 12 slices in the axial direction starting from the rind towards the center, and each set of two slices symmetrically located within the cheese relative to the center were thoroughly mixed in order to obtain six final samples for analysis. The samples were frozen at $30^{\circ} \mathrm{C}$ in Whirl-pack ${ }^{\mathrm{TM}}$ vacuum bags (Cole Parmer, Chicago, IL, USA) until physical and biochemical analyses were in order.

\section{Chemical analyses}

The fat and moisture contents of all cheeses were determined according to the method of Gerber-Van Gulik (Anon, 1975a,b) and the method of the atmospheric oven at $100^{\circ} \mathrm{C}$ for $24 \mathrm{~h}$, respectively (Case et al, 1985).

\section{Biochemical analyses}

Samples for water soluble peptide (WSP) assays were prepared as follows: $10 \mathrm{~g}$ of a cheese sample were homogenized with $90 \mathrm{~mL}$ of water for $3 \mathrm{~min}$ in a Stomacher Lab-Blender 400 (Seward Medical, London, UK) using sealed bags. These bags were held at $40^{\circ} \mathrm{C}$ for $1 \mathrm{~h}$, and the homogenates were centrifuged at $10000 \mathrm{rpm}$ for $30 \mathrm{~min}$. The supernatant was then decanted and filtered through a $0.22 \mu \mathrm{m}$ Syrfil filter (Nuclepore, Cambridge, MA, USA) to remove casein micelles in suspension. The concentration of WSP was measured by the Folin-Lowry method (Robyt and White, 1987) at $750 \mathrm{~nm}$. Sheep albumin (Sigma Chemical, St Louis, MO, USA) was used as the standard. The concentration of WSP was expressed as mg equivalent of sheep albumin (SA) per g of nonfat dry matter (NFDM) of cheese. NFDM was calculated for each cheese slice using experimental information on both fat and moisture contents determined as detailed earlier.
Diethyl ether soluble fat samples were prepared as follows: $10 \mathrm{~g}$ of cheese were macerated with $6 \mathrm{~g}$ anhydrous sodium sulfate (Merck, Darmstad, Germany) in a screw-capped bottle, and $60 \mathrm{~mL}$ of diethyl ether (Merck) were finally added. The homogenate was then stirred for 1 h, ultrasonicated for $1 \mathrm{~min}$ in a Sonorex RK100 (Bandelin, Berlin, Germany), stirred for an extra hour and filtered through no 1 paper (Whatman, Maidstone, UK). The precipitate in the bottle was resuspended in $40 \mathrm{~mL}$ diethyl ether, filtered and pooled with the previous filtered diethyl ether extract. Fat acidity (FA) was measured by titration of the diethyl ether soluble fat extract with 0.01 $\mathrm{N}$ ethanolic solution of potassium hydroxide (Merck) using phenolphthalein as indicator (Anon, 1991). FA was expressed as mmol per $100 \mathrm{~g}$ of fat; the fat content of each cheese slice was experimentally determined as detailed in the previous subsection.

\section{Experimental design}

Three time periods within the lactation season were considered (corresponding to the months of November, February and May in an attempt to properly represent autumn, winter and spring, respectively), four points within the ripening period $(0,7,21$ and 35 days) and six axial positions within the cheese (slice 1 or rind, to slice 6 or center). $A 3 \times 4 \times 6$ full factorial design replicated twice was thus generated (Box et al, 1978) as a basis for the performance of the experiments.

\section{Statistical analyses}

Statistical analyses were based on the ANOVA table method and were performed with the aid of the Statview package (Abacus Concepts, Berkeley, CA, USA). Validity of this methodology is ensured only if the experimental errors are independent and normally distributed and if variance is constant. Since our original data, $y$, failed to satisfy these assumptions, they had to be mathematically transformed into:

$$
\frac{y^{\lambda}-1}{\lambda \dot{y}^{\lambda-1}}
$$

where $y$ denotes the geometric mean of the original data and parameter $\lambda$ is determined according to the likelihood estimation method (Box et al, 1978), prior to application of the ANOVA methodology. In 
order to more easily understand the experimental information generated, and since the conclusions obtained on the statistical significance of the transformed data are also fully valid for the original data (Box et al, 1978), those data associated with statistically significant factors were transformed back into the original form and eventually plotted. In order to further refine the analysis of significance, all possible pairwise comparisons were performed using a multiple $t$-statistic as reference (a test $\mathrm{u}$ sually known as Fisher's protected least significant difference test).

\section{RESULTS}

\section{Proteolysis}

The two time variables (ie, the ripening time, $T$, and the position in the lactation season, S) and the space variable (ie, the axial location within the cheese, $L$ ) have statistically significant effects on the concentration of WSP $(P<0.0001)$. The importance of the factors chosen was smallest for the axial location (with an F ratio of the sum of squares associated therewith to the sum of squares of experimental residuals, $F$, of 6.4 , and a percent fraction of the sum of squares associated therewith to the whole sum of squares, $R$, of $6.2 \%$ ) and highest for the ripening time ( $F=95.3$ and $R=55.4 \%$ ) in terms of the concentration of WSP. The interaction $T S$ was the single second-order interaction associated with a statistically significant effect on the concentration of WSP $(F=5.6$ and $R=6.6 \%$ ). It could also be concluded that the concentrations of WSP: i) were statistically different between the curd and the cheese after 1 week $(P<0.0001)$ and between the 7 and 21-day-old cheese $(P<0.0001)$, but not between the cheeses thereafter $(P=0.18)$; ii) were statistically different between slice 1 and all the five inner slices, which showed to be statistically similar to one another at the $5 \%$ significance level; and iii) were statistically different between autumn and spring, between winter and spring $(P<0.0001)$, as well as between autumn and spring although at a higher level of significance $(P=0.0057)$.

Although the concentration of WSPs in the curds did not exhibit significant variations throughout the lactation season $(P=0.58)$, this observation did not hold for the 35-day-old cheeses $(P=0.004)$. Fully ripened cheeses in autumn (fig 1a) showed the lowest concentrations of WSP (ca $417 \mathrm{mg}_{\text {equivsa }} / \mathrm{g}_{\text {NFDM }}$ ) whereas the highest values were observed in the spring (ca $706 \mathrm{mg}_{\text {equivsA }} / \mathrm{g}_{\mathrm{NFDM}}$ ) counterparts (fig 1c). Profiles of the concentration of WSP versus the axial location within cheese during ripening were similar throughout the lactation season (fig 1). Based on the values obtained for the concentration of WSP, it was apparent that after 7 days of ripening there was a significant departure of the behavior exhibited by the rind (ie, slice 1) relative to that exhibited by the bulk of the cheese. For 35-day-old cheese, the rind showed the lowest concentration of WSP ( $347 \mathrm{mg}_{\text {equivSA }} / \mathrm{g}_{\mathrm{NFDM}}$ ), the center of the cheeses (ie, slice 6) the highest values (557 mgequivSA $/ g_{\text {NFDM }}$ ) and departure of the bulk from the rind behavior increased quantitatively from autumn (456 vs 264 mg gquiv. $_{\text {e }}$ SA $/$ g $_{\text {NFDM }}$ ) to spring ( 814 vs 363 mgequiv$\mathrm{SA} / \mathrm{g}_{\mathrm{NFDM}}$ ). The variations of the concentration of WSP were relatively fast at the initial stages of ripening and eventually tended to a plateau as time elapsed (fig 1).

The ripening time and the period within the lactation season were statistically significant $(P<0.0001$ and $P=0.0002$, respectively) in terms of proteolysis rate (calculated here as the change in the concentration of WSP between consecutive sampling times within the ripening period divided by the corresponding time interval), whereas the axial location within the cheese was on the edge of statistical significance according to common standards $(P=0.058)$. Considering the bulk of the cheese (ie, 
a
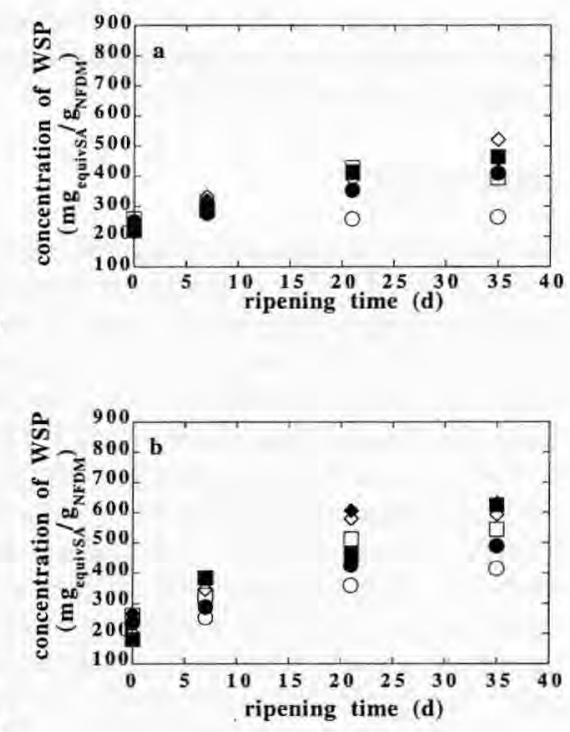

b

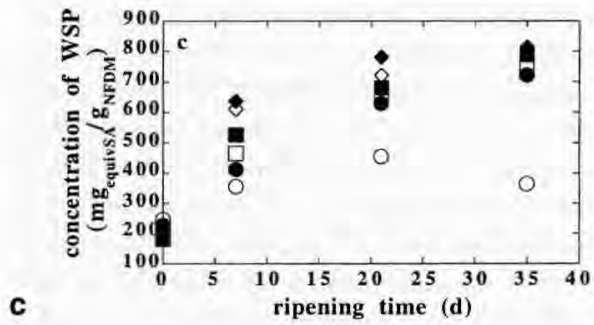

Fig 1. Concentration of the water soluble peptides (WSP) throughout ripening in (a) autumn, (b) winter and (c) spring periods for slices 1 (rind, O), $2(\bullet), 3(\circlearrowright), 4(\square), 5(\diamond)$ and 6 (center of the cheese, $\bullet$ ), as determined by the Folin-Lowry method.

Concentrations des peptides solubles dans l'eau (WSP) pendant la période d'affinage en (a) automne, (b) hiver, et (c) printemps pour les tranches 1 (croûte du fromage, O), $2(\bullet), 3(\square)$,

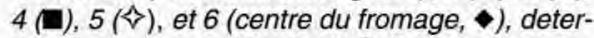
minées pour la méthode de Folin-Lowry.

slices 2 to 6 ), it could be observed that: $i$ ) for the first week of ripening, the rate of proteolysis showed the highest value (23.6 mgequivSA $/ \mathrm{g}_{\text {NFDM }} / \mathrm{d}$ ) and increased from autumn (8.7 mgequivSA $/ g_{\text {NFDM }} / \mathrm{d}$ ) to spring $\left(45.5 \mathrm{mg}_{\mathrm{e}}\right.$ -
quivSA $/ g_{\text {NFDM }} / d$ ); ii) between the first and the third week of ripening, the rates of proteolysis were below those of the former period (mean difference of $13.5 \mathrm{mg}_{\text {equiv- }}$ $\mathrm{SA} / \mathrm{g}_{\mathrm{NFDM}} / \mathrm{d}$ ), and the rates were higher in winter (12.3 $\mathrm{mg}$ equivSA $/ \mathrm{g}_{\mathrm{NFDM}} / \mathrm{d}$ ) and spring (11.8 $\mathrm{mg}$ equivSA $/ \mathrm{g}_{\mathrm{NFDM}} / \mathrm{d}$ ) and lower in autumn (6.1 $\mathrm{mg}$ equivSA $/ \mathrm{g}_{\mathrm{NFDM}} / \mathrm{d}$ ); and iii) between the third and fifth week of ripening, the rates of proteolysis were below those obtained during the previous 2 weeks (mean difference to winter season was $5.31 \mathrm{mg}$ equivSA $/ \mathrm{g}_{\mathrm{NFDM}} / \mathrm{d}$ ), without any apparent difference between periods within the lactation season (ca $4.8 \mathrm{mg}_{\text {equivSA }} / \mathrm{g}_{\mathrm{NFDM}} / \mathrm{d}$ ). The rates of proteolysis were lower on the surface $\left(4.03 \mathrm{mg}\right.$ equivSA $/ g_{N F D M} / \mathrm{d}$ ) of the cheese than in the bulk thereof, and the ripening time and period along the lactation season were not statistically significant at the $5 \%$ significance level $(P=0.29$ and $P=0.92$, respectively).

\section{Lipolysis}

The ripening time and the position in the lactation season had statistically significant effects at the $5 \%$ level on $\mathrm{FA}(F=403.3$ and $R=86.6 \%$, and $F=33.0$ and $R=4.7 \%$, respectively), but not the cheese axial location $(F=1.2$ and $R=0.4 \%$ ). None of the second-order interactions had a statistically significant effect on FA. It was also observed that the values of FA: i) were statistically different at the $5 \%$ significance level between the curd and the cheese after 1 week $(P<0.0001)$, between the 7 - and the 21-day-old cheese $(P=0.034)$, but not between the cheeses thereafter $(P=0.53)$; ii) were statistically similar between all slices at the $5 \%$ significance level; and iii) were statistically different between autumn and winter and between autumn and spring $(P<0.0001)$, but not between winter and spring $(P=0.64)$.

The FA of the curds manufactured in autumn $\left(0.64 \mathrm{mmol} / 100 \mathrm{~g}_{\mathrm{fat}}\right)$ was, on statistical grounds, significantly lower than that of 




Fig 2. Value of fat acidity (FA) throughout ripening in autumn (O), winter (P) and spring (J) periods, as determined by ethanolic acid/base titration.

Valeurs de lacidité de la matière grasse (FA) pendant la période d'affinage en automne (O),

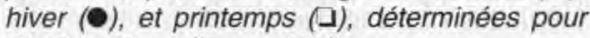
titration éthanolique acide/base.

the curds manufactured in both spring ( $\left.1.02 \mathrm{mmol} / 100 \mathrm{~g}_{\mathrm{fat}}\right)$ and winter $\left(1.48 \mathrm{mmol} / 100 \mathrm{~g}_{\text {tat }}\right)$; however, the FA obtained in the cheeses after 35 days of ripening was highest in spring $(11.9 \mathrm{mmol} / 100$ $\left.\mathrm{g}_{\text {iat }}\right)$ and lowest in autumn $(6.6 \mathrm{mmol} / 100$ gfat) (fig 2).

Irrespective of the period within the lactation season considered, the lipolysis rate (calculated here as the change in the FA between consecutive sampling times within the ripening period divided by the corresponding time interval) for the first week (0.95 mmol/100 g $\mathrm{gat} / \mathrm{d})$ was significantly higher than for the remaining ripening period $(0.09$ and $0.04 \mathrm{mmol} / 100 \mathrm{~g}$ fat $/ \mathrm{d}$, respectively). During the first week, it was also observed that the lipolysis rate was significantly lower for the autumn period $\left(0.77 \mathrm{mmol} / 100 \mathrm{~g}_{\mathrm{fa}} / \mathrm{d}\right)$ than for the winter and spring periods (which showed rates of 1.11 and $0.96 \mathrm{mmol} / 100 \mathrm{gfat} / \mathrm{d}$, respectively). For the following 2 weeks of ripening, the lipolysis rate did not decrease in spring $(0.20 \mathrm{mmol} / 100 \mathrm{~g} \mathrm{fat} / \mathrm{d})$ as much as in autumn $\left(0.036 \mathrm{mmol} / 100 \mathrm{~g}_{\mathrm{tat}} / \mathrm{d}\right)$ and winter $\left(0.034 \mathrm{mmol} / 100 \mathrm{~g}_{\mathrm{ta}} / \mathrm{d}\right)$. By the end of ripening (last 2 weeks), the lipolysis rate was lower in autumn $(0.003 \mathrm{mmol} / 100 \mathrm{gfat} / \mathrm{d})$ than in winter $(0.015 \mathrm{mmol} / 100 \mathrm{~g} \mathrm{fta} / \mathrm{d})$ and in spring $\left(0.092 \mathrm{mmol} / 100 \mathrm{~g}_{\mathrm{fa}} / \mathrm{d}\right)$.

\section{DISCUSSION}

The samples of curd exhibited low levels for WSP and FA; this observation was expected, however, because it is well established that freshly secreted milk contains small amounts of peptides and amino acids, on the one hand, and free fatty acids, on the other, which are not necessarily the result of proteolysis (Reiter et al, 1969) and lipolysis (Needs and Anderson, 1984), respectively. Differences in FA in the curd throughout the lactation season were also expected because the fat composition of ewe's milk varies within fairly wide limits, and these limits are a direct function of the composition of the feed (Ramos and Juarez, 1981) which in turn depends on such seasonal factors as the weather (the livestock is predominantly fed with silage during winter and with fresh grass during spring). The lactation season of Bordaleira ewes usually starts in October and ends in June; therefore, the November milk collection is representative of an initial stage, February of a middle stage and May of a final stage of lactation. Ramos and Juarez (1981) reported that titratable acidity tended to increase with advancement within the lactation season, being highest after about 3 months from the beginning thereof; titratable acidity then tended to decrease up to 5 months, and increase again towards the end of the lactation season.

The increases in WSP and FA were highest in spring and lowest in autumn. In addition to the aforementioned variation in the milk composition, this fact may be partly explained by differences in the ripening conditions, especially the temperature and the water activity (Lawrence et al, 1987); temperature is higher during spring than during autumn in the Serra region, and the salt to water ratio is lower in autumn than in spring 
(Macedo et al, 1994a). As ripening time elapses, the observed rates of both proteolysis and lipolysis in our experimental cheeses decrease most probably because the natural substrates for the two enzymecatalyzed processes (casein and triglycerides, respectively) are gradually depleted.

From the observation by Macedo et al (1994a) that after 7 days of ripening the salt levels and $\mathrm{pH}$ values at the surface and in the interior of the cheese are statistically different from one another, statistical differences in the WSP concentrations between the surface (ie, the rind) and the interior of the cheese (ie, the bulk) would be expected because the catalytic activity of proteinases (contributed by the vegetable rennet and the microbial flora) is affected by both $\mathrm{pH}$ and ionic strength (which is directly related to the salt concentration), and the rates of growth of those microbes able to synthesize proteinases are affected by both $\mathrm{pH}$ and water activity (which is directly related to the salt concentration as well). Our results have indicated that the lower WSP concentrations occur on the rind, a fact that may be partly accounted for by the higher salt to moisture ratio on the surface of the cheese when compared with the interior (Macedo et al, 1994a); in addition, the observed differences of the concentration of WSP and FA between the rind and the bulk are highest in the spring, the period for which the differences in the salt to moisture ratio are also maximal (Macedo et al, 1994a). In terms of FA, statistically significant differences between the surface and the interior of the cheese could not be observed. Two possible alternative explanations may be provided for this observation: either fat breakdown in Serra cheese i) is mainly associated with native milk lipases (Anon, 1991) or lipases present in the crude vegetable rennet as contaminants, both of which are expected to be uniformly distributed throughout the cheese, or ii) is mainly associated with lipases produced by microorganisms which grow more actively during the first week of ripening (Macedo et al, 1994a), the most intense period of lipolysis. Possible support for the microbial arguments on proteolysis (Fox, 1981) and lipolysis may be obtained by realization that the predominant microflora in Serra cheese are lactic acid bacteria ( $L A B)$, coliforms and yeasts, especially Leuconostoc lactis, Lactoccoccus lactis ssp lactis, Lactobacillus paracasei, Hafnia alvei and Sporobolomyces roseus (Macedo et al, 1994b). Although LAB show, in general, considerably high proteolytic but relatively low lipolytic activities (Choisy et al, 1987), such psychrotrophic bacteria as pseudomonas and coliforms are known to secrete thermoresistant proteinases (Grappin et al, 1985) and lipases (Anon, 1991). Furthermore, $P$ fluorescens exhibits relatively high rates of production of lipases in cheese which are seriously impaired by decreasing $\mathrm{pH}$ (Stead, 1986), a situation which occurs during the first week of ripening in Serra cheese as a result of the action of $L A B$ (Macedo et al, 1994a).

Although this study attempted to show statistically different behaviors of proteolysis and lipolysis in Serra cheese in terms of two time variables and one space variable, the empirical rationale presented relating the microflora and these two enzyme-driven processes requires further fundamental studies for complete verification without which understanding of the ripening process will not be fully possible.

\section{ACKNOWLEGMENTS}

The authors are grateful to the members of the technical board of ANCOSE (the Portuguese Association of Breeders of Serra da Estrela) for their cooperation encompassing the local manufacture and transport of the cheeses to the ESB premises. Financial support for $A C$ Macedo was provided by a PhD fellowship (CIENCIA BD1741/91-IF). Financial support for ML Costa was provided by a training fellowship (PEDIP). This project was funded by research grants provided by $\mathrm{Al}$ (the Portuguese Innovation Agency) within 
the R\&D project Improvement of traditional cheeses and their technology (MAQUETTE) and by AAIR (European Community) within the R\&D project Design and production of an enzymatic and microbial mixture to improve the process ewe's cheese (Spain, France, Italy and Portugal) safety and quality and to get a novel functional food as a response to European demand for new products low in cholesterol and protein enriched.

\section{REFERENCES}

Anon (1975a) Détermination de la teneur en matière grasse - norme internationale ISO 3432 . In: Organisation Internationale de Normalisation - Fromages

Anon (1975b) Détermination de la teneur en matière grasse - norme internationale ISO 3433. In: Organisation Internationale de Normalisation - Fromages

Anon (1991) Basic principles of the methods used for free fatty acid determination. In: Determination of Free Fatty Acids in Milk and Milk Products. FILIDF Bull 265, 8-18

Antunes TM, Santos I (1943) Elementos para o estudo do queijo da Serra. Bol Pecu 11, 61-90

Barbosa M (1986) Serra da Estrela cheese. FILIDFBull 202, 133-134

Box GEP, Hunter WG, Hunter JS (1978) Statistics for Experimenters. An Introduction to Design, Data Analysis, and Model Building. John Wiley, New York

Case RA, Bradley RL, Williams RR (1985) Chemical and physical methods. In: Standard Methods for the Examination of Dairy Products (GH Richardson, ed) American Public Health Association, Washington DC, USA

Choisy C, Desmazeaud M, Gripon JC, Lamberet G, Lenoir J, Tourneur C (1987) Os fenómenos microbiológicos e enzimáticos, e a bioquímica da cura (afinação). In: O Quelijo (A Eck, J Hermier, J Lablee, J Lenoir, F Weber, eds; R Casquilho, trad) Publicaçōes Europa-América, Mem Martins, pp 102-149
Cruz AA, Borrego JD (1948) Queijo à ovelheira e queijo à cabreira. Bol Pecu 16, 17-25

Fox PF (1981) Proteinases in dairy technology. Neth Milk Dairy J 35, 233-245

Grappin R, Rank TC, Olson NF (1985) Primary proteolysis of cheese proteins during ripening: a review. $J$ Dairy Sci 68, 531-540

Lawrence RC, Creamer LK, Gilles J (1987) Texture development during cheese ripening. J Dairy Sci 70 , 1748-1760

Macedo AC, Malcata FX, Oliveira JC (1993) The technology, chemistry, and microbiology of Serra cheese: a review. J Dairy Sci 76, 1725-1739

Macedo AC, Costa ML, Malcata FX (1994a) Characterization of the microflora of Serra cheese: evolution throughout ripening time, lactation period, and axial location. Int Dairy J 4, 1-16

Macedo AC, Malcata FX, Hogg TA (1994b) Microbiological profile in Serra ewes' cheese along ripening. J Appl Bacteriol 79, 1-11

Needs EC, Anderson MJ (1984) Lipid composition of milks from cows with experimentally induced mastitis. J Dairy Res 51, 239-249

Ramos MM, Juarez M (1981) The composition of ewe's milk and goat's milk. FILIDF Bull 140, 5-8

Reiter B, Sorokin Y, Pickering A, Hall AJ (1969) Hydrolysis of fat and protein in small cheeses made under aseptic conditions. J Dairy Res 36, 65-76

Robyt JF, White BJ (1987) Biochemical Techniques. Theory and Practice. Wavelend Press, Prospect Heights, IL, USA

Santos IA (1957) O queijo da Serra. Bol Pecu 25, 5-17

Stead D (1986) Microbial lipases: their characteristics, role in food spoilage and industrial uses. $J$ Dairy Res $53,481-505$

Vieira de Sá F, Barbosa M (1982) Technological study of Serra da Estrela cheese-making. In: Proc IDF Congr, Moscow, Russia, V1B1-462

Vieira de Sá F, Machado BR, Pinto OR, Cruz IV, Carneiro MD, Barbosa M, Reis MC (1970) Química e Biologia: Maturação em queijos de ovelha Serra e Serpa. Livraria Portugal, Lisbon, Portugal 